\title{
THE INFLUENCE OF NORDIC WALKING ON PHYSICAL FITNESS OF ELDERLY PEOPLE
}

Vaida Šokelienė, Vida Janina Česnaitienè

\author{
Lithuanian Academy of Physical Education, Kaunas, Lithuania
}

\begin{abstract}
Research background and hypothesis. Nordic Walking is a form of physical activity which is rapidly gaining its popularity and is suitable for people of various ages and health conditions. We hypothesized that after 12 weeks of Nordic Walking exercises elderly people would experience certain changes, including increased flexibility of the lumbar spine area, increased strength endurance of the lower limbs, better aerobic endurance, decreased proportional fat mass.

Research aim was to determine and asses the influence of Nordic Walking on the physical capability of elderly people.

Research methods. The study included 41 subjects (11 men and 30 women): their average age was $65 \pm 5$ years. Physical activity of the subjects was evaluated according to their physical activity level and intensity evaluation questionnaire (RAPA). In order to determine physical fitness of the subjects we performed calf endurance test based on P. Mark and S. Tremblay's (1992) proposed methodology, lumbar spine flexibility was evaluated by the "sitreach" test, spirometry, aerobic endurance test. The subjects performed Nordic Walking training sessions two times a week. The duration of the study was 12 weeks.

Research results. The people who engaged in the Nordic Walking practice sessions showed improved indicators of aerobic endurance, smaller body mass and lower ratio of waist/hip sizes. The flexibility of the lumbar spine area increased for the people who had been physical inactive.

Discussion and conclusions. Nordic Walking holds a positive impact on the physical capability of elderly people. Engagement in the Nordic Walking exercises has a more obvious effect on the physical capability of the people who are less physically active than of the people who are more physically active.
\end{abstract}

Keywords: physical activity, training, aging.

\section{INTRODUCTION}

$\mathrm{T}$

The aging of human locomotor system is related to the constant decrease of muscle mass, strength, and power of contraction. Studies have shown that physical activity increases and helps maintain muscle strength and power, which provides the elderly's independence and unconstrained movement ability. People who have been inactive all their life and those who have started exercising at old age also felt positive results (Gaigalienè, 1999). Nordic Walking (NW) is one of the fastest-growing forms of physical activity in northern Europe, Scandinavia and Germany. This form of exercise is suitable for all ages. NW is safe, inexpensive, easy to get started sport with health benefits, intended for a pleasant leisure, but not for competitions. In 
Finland, this type of sport engaged more than 850,000 inhabitants in 2008. In the world, it engaged 6 million people in 2005 and about 8.5 million in 2008 (INWA). There are many studies done showing the benefits of NW for people with various health problems (Church et al., 2002; Hansen et al., 2008). However, little is known how much NW may be useful for healthy elderly people. It was found that walking with sticks, unlike running, removes part of the load burden for leg joints and back, also correctly performed movements relax neck and shoulder muscles. Walking with sticks improves the capability of the cardiovascular system, and increases aerobic endurance. Studies have shown that this activity increases metabolism (Geyer, 2005). Therefore, the aim of this study was to evaluate the influence of NW on the physical fitness of elderly people.

\section{RESEARCH METHODS}

The study included 41 subjects, with an average age of $65 \pm 5$ years. Further characterization of the subjects is presented in Table.

The participants filled the form of physical activity levels and intensity evaluation suggested by the Health Promotion Research Center at the University of Washington (Topolski et al., 2006). The objective of the survey was to assess the physical activity of the subjects. The subjects' height was established with the gauge. Body mass measurements were evaluated by using body composition analyzer "TBF-300 (Germany), waist and hip size were assessed with the tapemeasure.

In order to evaluate the flexibility of lumbar spine we used "Sit-reach" test of EUROFIT test batery, and calves endurance test conducted by P. Markon and S. Tremblay (1992) proposed methodology. The functional state of the respiratory system was assessed with a spirometer by measuring the vital capacity of the lungs. Aerobic endurance was evaluated using Roufier-Dixon index.

During the whole study the heart rate (HR) was recorded using pulse monitor Polar S810 (Finland). The goal of the pulsometry was to measure the subjects' HR during all trials, according to which we individually selected safe and beneficial workloads for the subjects. The load was determined and controlled individually, according to the results of the HR after each workout.

The results were analyzed using the statistical package SPSS 17.0 for Windows. The impact of the NW was determined by the analysis of non-parametric criteria. To compare dependent variables we used Wilcoxon's test and for the independent-Kolmogorov-Smirnov $\mathrm{Z}$ test. All results were considered statistically significant when $\mathrm{p}<0.05$.

The detailed protocol of the study is provided in Figure 1.

During the first testing we evaluated all physical qualities of the three groups of subjects (lumbar spine flexibility, lower limb strength-endurance,
Table. Characteristics of the subjects

\begin{tabular}{|l|c|c|c|c|c|c|}
\hline \multicolumn{1}{|c|}{ Groups of subjects } & Men & Height, cm & Weight, kg & Women & Height, cm & Weight, kg \\
\hline $\begin{array}{l}\text { Group 1 } \\
\text { PA subjects }\end{array}$ & 3 & $1.69(0.1)$ & $64.53(9.64)$ & 8 & $1.62(0.08)$ & $56.39(9.55)$ \\
\hline $\begin{array}{l}\text { Group 2 } \\
\text { PINA subjects }\end{array}$ & 4 & $1.82(0.05)$ & $92.15(10.22)$ & 10 & $1.62(0.05)$ & $72.34(9.49)$ \\
\hline $\begin{array}{l}\text { Group 3 } \\
\text { Control group }\end{array}$ & 4 & $1.76(0.07)$ & $82.1(7.37)$ & 12 & $1.63(0.06)$ & $70.1(13.67)$ \\
\hline
\end{tabular}

Figure 1. The protocol of the research

Note. Tr. - training

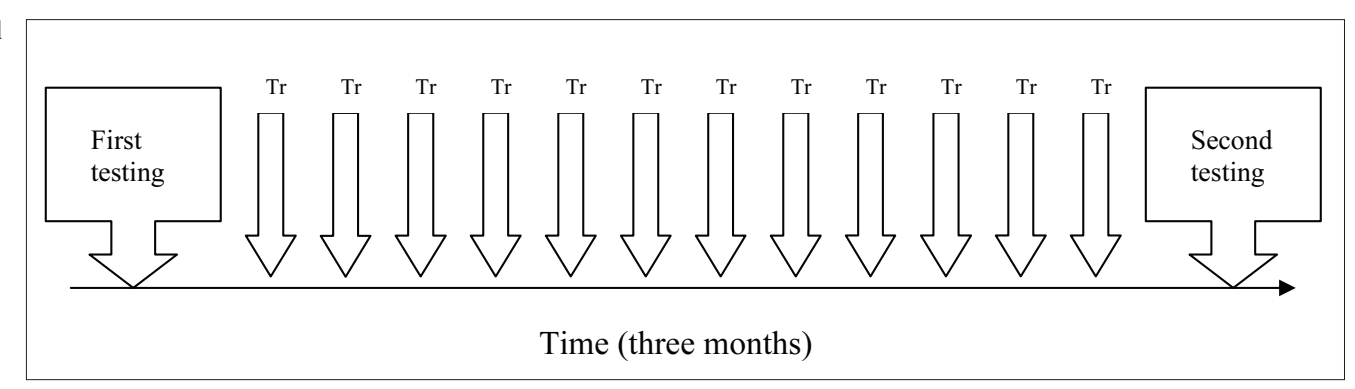


vital capacity of lungs, aerobic endurance). We also assessed their stature, waist and hip size and body weight.

The first and the second groups of subjects participated in NW workouts. The workout plan was as follows: a 10-minute warm-up, 35-minute main part, and 5-minute stretching routine. During basic training the subjects walked on a smooth area. In accordance with the American College of Sports Medicine recommendations exercise intensity $-50-85 \%$ of maximum HR was chosen.

The second testing was identical to the first one.

\section{RESEARCH RESULTS}

The changes of body weight mean values of the subjects are given in Figure 2. Average body weight of PA (PA) subjects decreased by 2 percent after training $(\mathrm{p}<0.05), 5$ percent in PINA (PINA) subjects $(\mathrm{p}<0.05)$, and the same weight remained in the control group.

The changes of subjects' waist/hip ratio after NW workouts are presented in Figure 3. Waist/ hip ratio mean values decreased in both groups of subjects (PA and PINA). PA subjects ratio decreased by $6 \%(\mathrm{p}<0.05)$, and in PINA subjects $21 \%(\mathrm{p}<0.05)$.
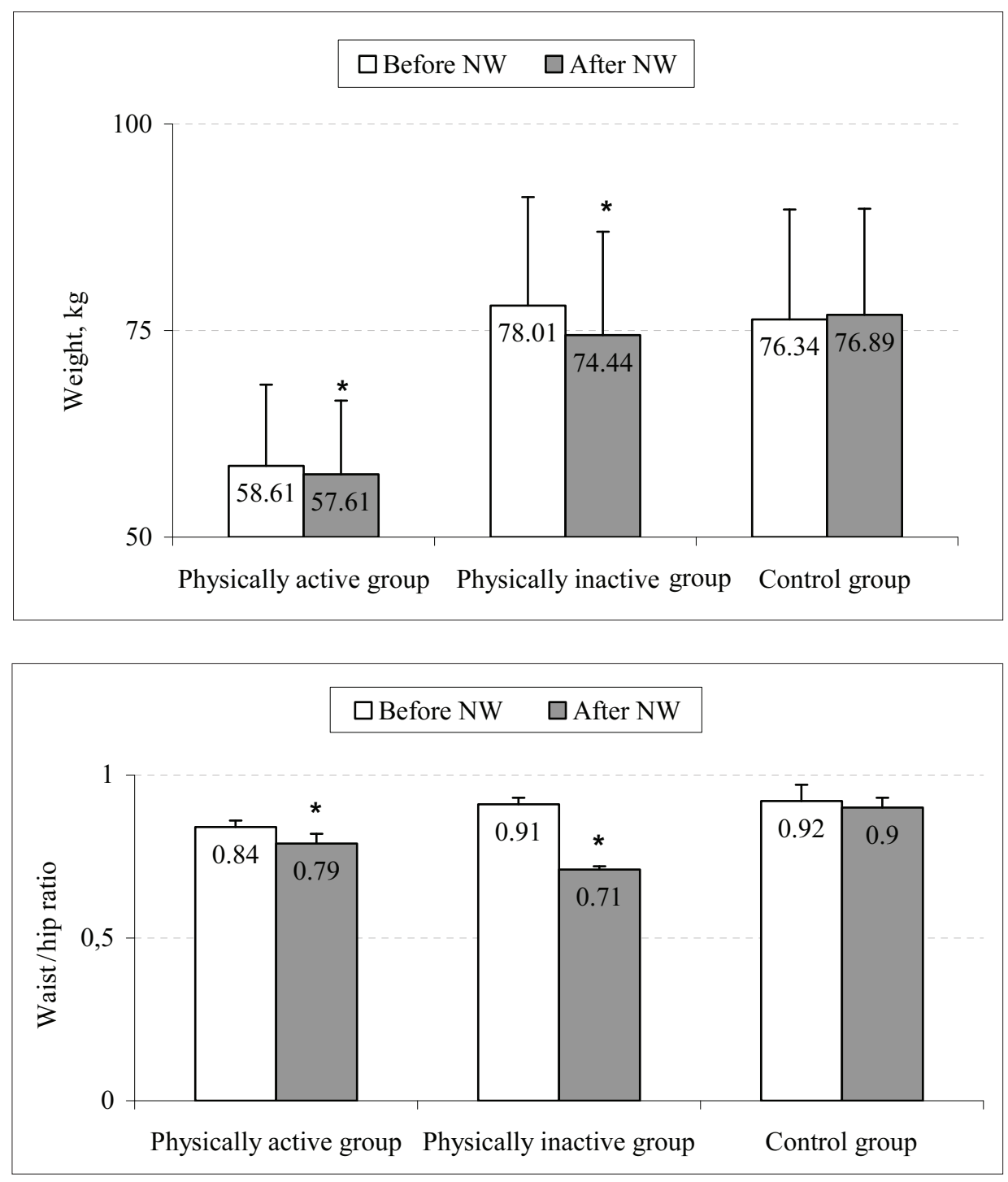

Figure 2. Subjects' body weight (kg) before and after NW training

Note.* $-\mathrm{p}<0.05$ compared to the body weight before the NW.

Figure 3. Obtaining the waist/ hip ratio before and after the Nordic Walking training

Note. $*-p<0.05$ compared to waist/hip ratio before the NW. 
Analysis of the flexibility of the lumbar spine (Figure 4) based on "sit-reach" test showed that the results of PA subjects increased by $0.64 \mathrm{~cm}$ $(\mathrm{p}>0.05)$, and the results of PINA subjects $2.64 \mathrm{~cm} .(\mathrm{p}<0.05)$.

Figure 5 illustrates calf endurance test results. The parameters did not change significantly in all subjects after NW training.

The results of vital capacity of the lungs test before and after NW training are presented in Figure 6. The vital capacity of the lungs in PA subjects after NW training increased from 2.331 to $2.65(\mathrm{p}<0.05)$ and in PINA - from 2.361 to 2.87 $(p<0.05)$. The vital capacity of the lungs in the control group did not change.

The results of subjects' aerobic endurance test before and after NW training are provided in Figure 7. The results showed that aerobic endurance of the PA and PINA subjects after NW training improved significantly $(p<0.05)$. Roufier-Dixon index in PA subjects decreased from 7.85 to 5.65, in PINA subjects Roufier-Dixon index declined from 6.16 to 5.31 , but RoufierDixon index increased from 5.22 to 5.48 in the control group.
Figure 4. Subjects' "Sit-
reach" test results before and after NW training $(\mathrm{cm})$
Note. $*-p<0.05$ compared to lumbar spine flexibility before the NW.

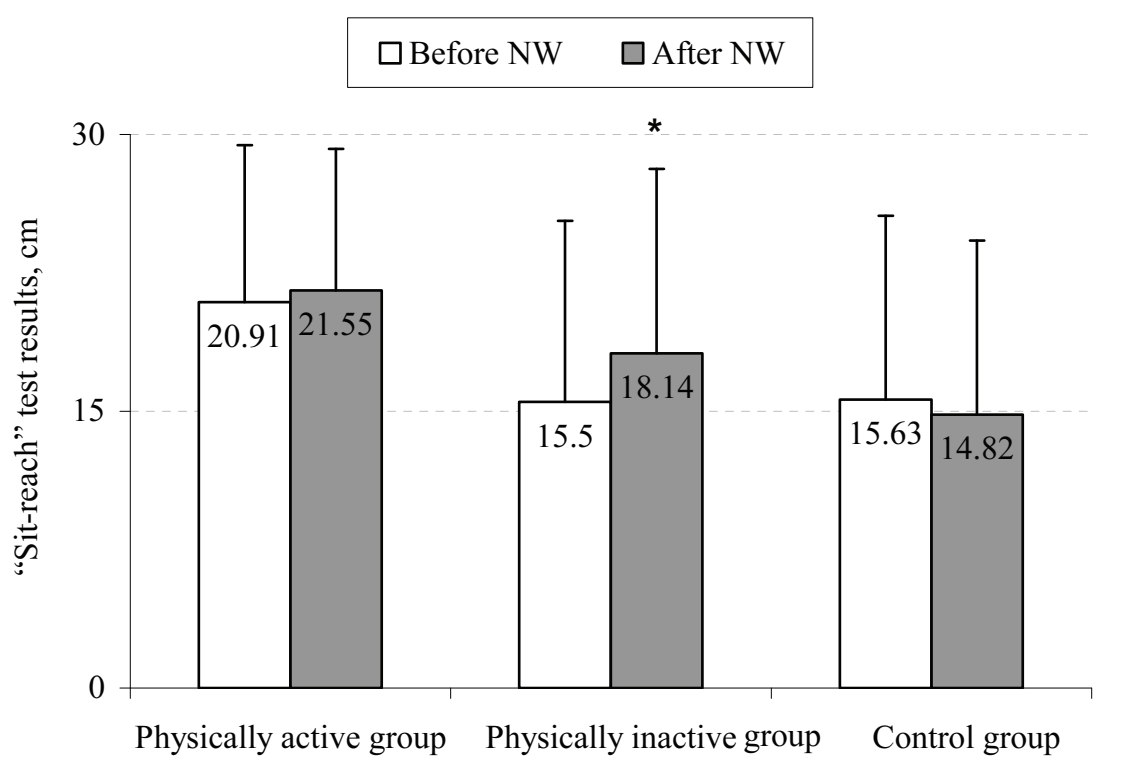

Figure 5. Subjects' calf endurance test results distribution before and after the NW training (times of standing on tiptoe/min)

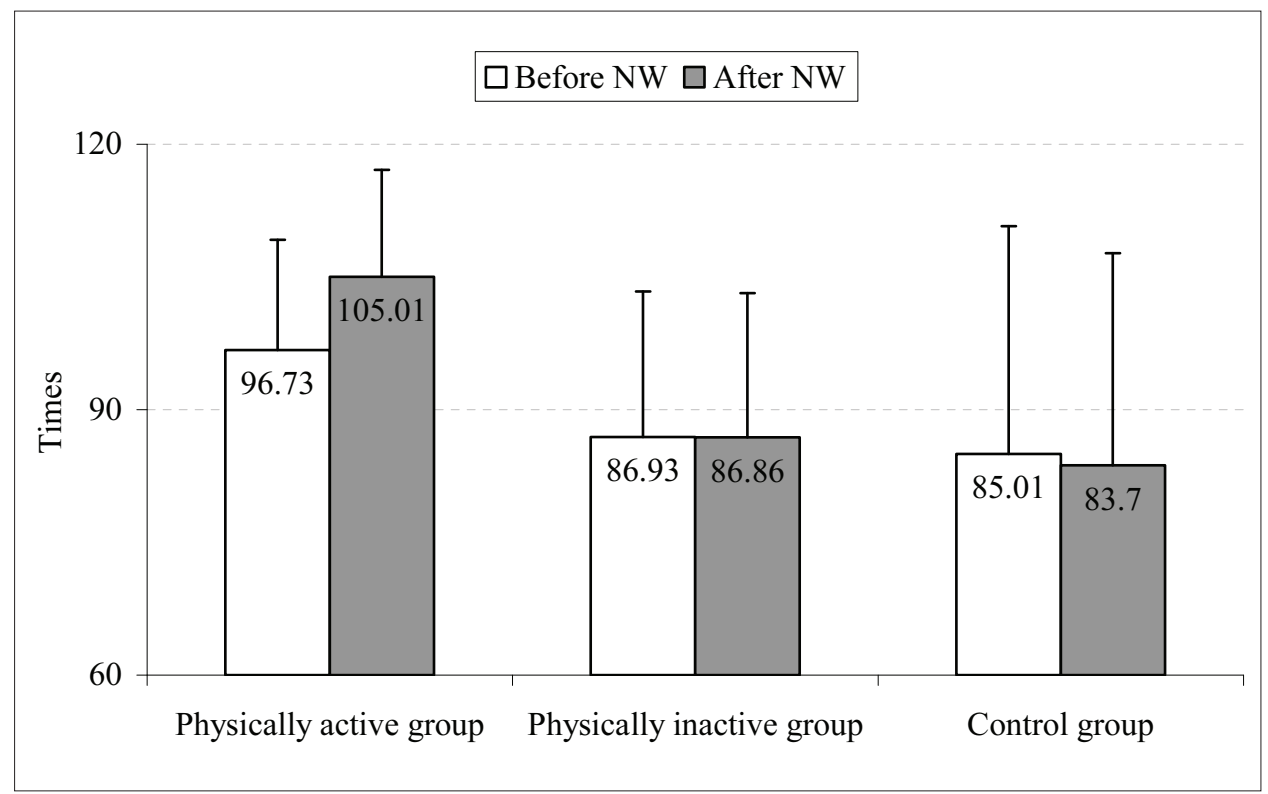



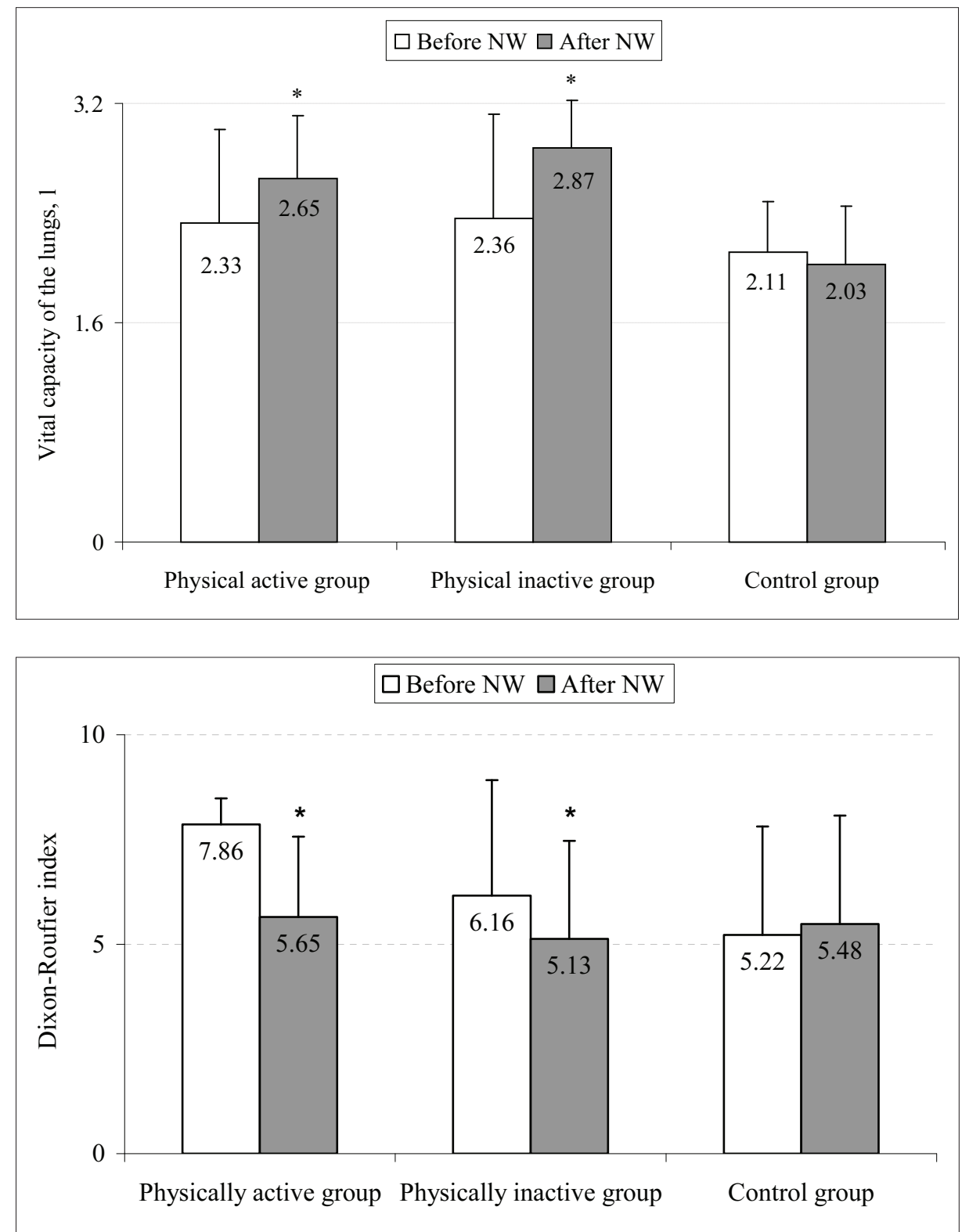

Figure 6. Subjects' vital capacity of the lungs before and after NW training

Note. ${ }^{*}-\mathrm{p}<0.05$ compared to the vital capacity of the lungs before NW.

Figure 7. Subjects' aerobic endurance test results before and after NW training (DixonRoufier index)

Note. $*-p<0,05$ compared to aerobic endurance before NW.

\section{DISCUSSION}

NW training significantly $(\mathrm{p}<0.05)$ reduced the body weight of subjects. It decreased in PA subjects by $2 \%$, and in PINA $-5 \%$. These results confirm the findings of M. Rogers and colleagues (2010) study, which showed that NW training reduced body weight by $22 \%$. However, T. S. Church and colleagues (2002) carried out an experimental the results of which argue the impact of NW training on body weight of subjects as it remained the same. However, many findings of foreign researchers confirm the positive effects of NW training for weight loss. They found that NW movements consume more calories than conventional walking (Church et al., 2002). W. Kohler's (2008) study showed that walking with sticks prevents age-induced decreased in bone density. Our study showed that waist/hip ratio of PA and PINA subjects after NW training significantly $(\mathrm{p}<0.05)$ decreased.

J. Hartvigsen and colleagues (2010) conducted the first study that evaluated the effect of NW for subjects with back pain. They noted that NW is a useful workout for people suffering from back pain. Our study results showed positive effect of NW on lumbar spine flexibility. Statistically significant $(\mathrm{p}<0.05)$ improvement of lumbar spine flexibility was found in PINA group $-2.64 \mathrm{~cm}$. The lumbar spine flexibility of PA subjects improved as well, but the difference was not statistically significant $(p>0.05)$. Lumbar spine flexibility deteriorated in the control group $0.81 \mathrm{~cm} .(\mathrm{p}>0.05)$. 
K. Kukkonen-Harjula and colleagues (2007) conducted a study which showed that triceps increased martedly after NW. They found the NWinduced increased upper body muscle endurance, but not strength. Our study did not reveal any effect of NW on leg endurance. The results of leg endurance test in all three groups of subjects after NW training did not show any statistically significant difference $(\mathrm{p}>0.05)$.

T. S. Church and colleagues (2002) found that NW induced an increase in oxygen consumption. Study showed that the NW increased oxygen consumption by $23 \%$. Our study results showed that PA subjects' vital capacity of lungs increased from 2.331 to 2.651 , and in PINA - from 2.361 to 2.871 .

Scientists suggest that aerobic endurance due to NW increase on average by about $20 \%$. This percentage may be higher depending on the intensity of the workload. This is especially relevant for people who want to burn more calories and have certain health problems (Church et al., 2002). Studies show that walking increases aerobic endurance in healthy people as well as in patients suffering from chronic diseases. The benefits of walking for the metabolic and physiological processes have also been demonstrated (Quelle et al., 2002). The main discovery of the study is demonstrated a positive effect of NW on people with a history of cardiovascular diseases. The results showed that after three months of NW (three times a week, 70\% intensity, 40-60 minutes a day), aerobic capacity of people with heart condition increased (Oka et al. 2000; Kocur et al., 2009). Our study showed that aerobic endurance were significantly $(\mathrm{p}<0.05)$ improved because of NW training in both PA and PINA subjects. PA subjects' Roufier-Dixon index decreased from 7.85 to 5.65, and in PINA group this index decreased from 6.16 to 5.31 .

\section{CONCLUSIONS AND PERSPECTIVES}

Nordic walking training had a positive effect on following investigated parameters of all subjects: aerobic endurance, body mass, waist/hip ratio, and in PINA subjects as well as the flexibility of lumbar spine.

\section{REFERENCES}

Breyer, M. K., Breyer-Kohansal, R., Funk, G. C. et al. (2010). Nordic Walking improves daily physical activities in COPD: A randomised controlled trial. Respiratory Research, 22, 11-112.

Church, T. S., Ernest, C. P., Morss, G. M. (2002). Field testing of physiological responses to Nordic Walking. Research Quarterly for Exercise and Sport, 73, 296-300. Gaigalienè, B. (1999). Pagyvenusiu žmoniu fizinis pajègumas, aktyvus gyvenimo būdas ir sveikata. Vilnius. Geyer, K. (2005). Mit Stokeinsatz zum Ziel. Physiopraxis, 4, S 36-38.

Hansen, L., Henriksen, M., Larsen, P., Alkjaer, T. (2008). Nordic Walking does not reduce the loading of the knee joint. Scandinavian Journal of Medicine and Science in Sports, 18, 436-441.

Hartvigsen, J., Marso, L., Bendix, T., Manniche, C. (2010). Supervised and non-supervised Nordic walking in the treatment of chronic low back pain: A single blind randomized clinical trial. BMC Musculoskeletal Disorders, 11-30.

International Nordic Walking Federation (INWA). (2010). [2010 04 03]. Internet link: http://inwanordicwalking.com.

Kocur, P., Deskur-Smielecka, E., Wilk, M., Dylewicz, P. (2009). Effects of Nordic Walking training on exercise capacity and fitness in men participating in early, short-term inpatient cardiac rehabilitation after an acute coronary syndrome - a controlled trial. Clinical Rehabilitation., 23 (11), 995-1004.

Kohler, W. (2008). Diagnostic algorithm for the differentiation of leukodystrophies in early MS. Journal of Neurology, 6, 123-126.

Kukkonen-Harjula, K., Hiilloskorpi, H., Manttari, M. et al. (2007). Self-guided brisk walking training with or without poles: A randomized-controlled trial in middleaged women. Scandinavian Journal of Medicine and Science in Sports, 17, 316-323.

Markon, P., Tremblay, S. (1992). L'aide au maintien a domicile puor les perssones agees: Favoriser l'autonomie. Universite du Quebec a Chicoutimi, 555.

Oka, R. K., De Marco, T., Haskell, W. L. et al. (2000). Impact of a home-based walking and resistance training program on quality of life in patients with heart failure. American Journal of Cardiology, 85 (3), 365-369.

Quelle, K. J., Porcari, J. P., Franklin, B. A. et al. (2002). Is brisk walking an adequate aerobic training stimulus for cardiac patients? Chest, 122 (5), 1852-1856.

Rogers, M., Blumberg, N., Heal, J., Langa, K. (2010). Utilization of blood transfusion among older adults in the United States. Medicine and Science in Sports and Exercise, 32 (3), 18-24.

Topolski, T. D., LoGerfo, J., Patrick, D. L. et al. (2006). The Rapid Assessement of Physical Activity (RAPA) among older adults. Prevention of Chronic Disease: Public Health Research, Practice and Policy, 3 (4), A 118. 


\title{
ŠIAURIETIŠKOJO ĖJIMO POVEIKIS VYRESNIOJO AMŽIAUS ŽMONIŲ FIZINIAM PAJĖGUMUI
}

\author{
Vaida Šokelienė, Vida Janina Česnaitienè \\ Lietuvos kūno kultūros akademija, Kaunas, Lietuva
}

\begin{abstract}
SANTRAUKA
Tyrimo pagrindimas ir hypotezé. Šiaurietiškasis èjimas (ŠE்) - vis populiarẻjanti fizinio aktyvumo forma, tinkanti bet kokio amžiaus ar sveikatos būklès žmonèms. Atlikta nemažai tyrimų, irodančių šiaurietiškojo èjimo naudą žmonèms, turintiems ivvairiu sveikatos sutrikimu (Church et al., 2002, Hansen et al., 2008; Rodgers et al., 2010). Visgi mažai žinoma, kiek ŠĖ gali būti naudingas sveikiems vyresniojo amžiaus žmonėms. Manome, kad po 12 savaičių ŠĖ pratybų padidèja vyresniojo amžiaus žmonių juosmeninès stuburo dalies lankstumas, kojų jègos ištvermè, pagerèja aerobinè ištvermè, sumažèja santykinè riebalų masè, keičiasi riebalų masès pasiskirstymas.

Tikslas: nustatyti ir ịvertinti šiaurietiškojo èjimo poveikị vyresniojo amžiaus žmonių fiziniam pajègumui.

Metodai. Buvo tiriamas 41 asmuo (11 vyrų ir 30 moteru), kurių amžiaus vidurkis $65 \pm 5$ metai. Tiriamujų fizinis aktyvumas nustatytas fizinio aktyvumo lygio ir intensyvumo vertinimo anketa (RAPA). Tiriamuju fiziniam pajegumui vertinti taikytas blauzdu ištvermès testas pagal P. Markon ir S. Tremblay (1992) metodika, juosmeninės stuburo dalies lankstumas ịvertintas testu „Sestis-siekti“, taikyta spirometrija, aerobinès ištvermès testas. Šiaurietiškojo èjimo pratybos vyko du kartus per savaitę. Tyrimas truko 12 savaičių.

Rezultatai. Po šiaurietiškojo ejimo pratybu pagerējo visų tiriamujų aerobinès ištvermès rodikliai, sumažejo kūno masé, juosmens ir klubų apimties santykis, padidejo fiziškai neaktyvių tiriamuju juosmeninės stuburo dalies lankstumas.

Aptarimas ir išvados. Šiaurietiškasis ejjimas teigiamai veikia vyresniojo amžiaus žmonių fizini pajègumą. Vyresniojo amžiaus žmonių, kurių fizinis aktyvumas nedidelis, fizinis pajègumas po šiaurietiškojo èjimo pratybu pagerèjo labiau nei fiziškai aktyvių.
\end{abstract}

Raktažodžiai: fizinis aktyvumas, treniravimas, senëjimas.

Gauta 2011 m. liepos 23 d.

Received on July 23, 2011 